\title{
Study and Modelization of Veterinary Drug Residue Kinetics on Sawdust as Absorptive Biomaterial in Eastern Algeria during January 2017 to June 2018
}

\author{
Berghiche Amine ${ }^{1,2^{*}}$, Khenenou Tarek ${ }^{2,3}$, Boulebda Nadji ${ }^{1,2}$, Slimi Khaled ${ }^{2}$, Boudis Tarek $^{2}$ and Labiad Ibtessam ${ }^{1,2}$ \\ ${ }^{1}$ Laboratory of Science and Technic of living Mohamed Cherrif Messaadia University, Souk Ahras, Algeria \\ ${ }^{2}$ Agro veterinary institute, Taoura, Mohamed Cherrif Messaadia University, Souk Ahras, Algeria \\ ${ }^{3}$ Laboratory of Animal Production, Biotechnology and Health, University of Mohamed Cherif Messaâdia, Souk Ahras, Algeria \\ *Corresponding author's Email: amine_berghiche@yahoo.com
}

\begin{abstract}
Sawdust, an affordable resource, is being investigated as an adsorbent to eliminate residual contaminants from water. Wood processing residues such as bark and sawdust have been widely studied for some years for their adsorption and removal properties of toxic metals contained in contaminated effluents. The aim of our study is to know the source of chemical contamination of water by using spectrophotometry methods in field ultraviolet, the kinetic study of sodium salicylate adsorption on sawdust was modelized according to two kinetic models (pseudo first and second order), to determine the most optimal pattern to describe this phenomenon, was based in the comparison on the correlation coefficient $\left(\mathrm{R}^{2}\right)$ between the absorbance and the wavelength for both models and evaluate the optimal time of contact solid/liquid. Present results indicated that the correlation coefficient $\left(\mathrm{R}^{2}=0.999\right)$ for the pseudo-second order, which means that this model is the best for future studies in the kinetics of adsorption of sodium salicylate by sawdust, with a time of contact solid /liquid optimal is 44.5 minutes.
\end{abstract}

Key words: Residual contaminants, Sodium salicylate, Spectrophotometry, Veterinary drugs

\section{INTRODUCTION}

Water is being one of the most basic constituents of life and essential resource for the development of the world, during the last century, the pressure growing on the water resources due to the demographic and economic growth resulted in considering various approaches for the stock management out of water (Meadows, 2012). Today, huge advance has been made in agriculture to meet the global nutritional needs of the population. This requires a contribution of fresh water to about $70 \%$ of global consumption (Derelanko, 2017) the use of water in agriculture faces social, economic and environmental problems that cannot be easily reconciled (Figuière et al., 2018; Juan et al., 2018; Toillier, 2018). The presence of the primary pollutants (residues of drugs) in the aqueous environmental matrices has become a subject of concern the fields of the environment and the public health (Jones et al., 2004). Because the analytical techniques improved the chemical products were identified in the water resources with concentrations varying from some NanoGrams (ng) to several hundred micrograms per liter (Charuaudet al., 2018), consequently, it became essential to carry out an evaluation of the environmental and medical risks of the complex mixtures of organic micro-pollutants particularly in aquatic environments (Harris, 2010).

However, it would not be realistic to put forward repeated measures indefinitely, in time and space, to seek, identify and quantify all the residues of drugs present in the environment. Therefore, it is important to try a model to evaluate its principal families of medicines residues, minimizing the present risks at low dose during chronic exposures (Limbuet al., 2018). The adsorption of organic molecules on modified materials has proven to be a very effective treatment technique, but this efficiency makes the cost of the operation excessive (Gupta, 2011). Over the last two decades, many researchers have focused on the preparation of certain adsorbents from natural fruit tree waste (Arami et al., 2005; Forgacs et al., 2004), palm trees (Hazourli et al., 2007) or sawdust (Pekkuz et al., 2008). These natural absorbents, which are available at very low cost, have been shown to be effective against organic molecules at the laboratory scale, for example wood studies (Ho and Mckay, 1998), tree fern (HO et al., 2005) and palm fibres (Ofomaja, 2007). For the valorization of these adsorbents, the research focused on the study of the mechanisms governing the fixation of dye molecules on the grains fibres of the adsorbents (Aloulou et al., 2004). Wood is a building material whose industrial transformation generates byproducts and saw dusts, used for other purposes such as energy valorization like fuel and clean adsorbent for the water treatment worn. However, the valorization of the sawdust-like support adsorbing in the purification of used water, requires knowledge of structure and texture of the material (Kyzas, 2013). The capacity of the sawdust to fix adsorbents 
such as pollutants can be largely improved while making it undergo a chemical treatment. The modification of wood can be made using sulfuric acid, phosphoric acid or by enzymes (Zhang, 2006).

Sodium salt of the salicylic acid, also called Sodium Salicylate (SS), obtained by action of the sali-cylic acid on sodium bicarbonate, it is presented in the form of colorless and odorless crystals. It is used as analgesic and antipyretic, and is employed for the treatment of the rheumatic effects. Adsorption with the interface solid water / solution is a physical or chemical phenomenon by which molecules or ions present in a liquid waste "adsorbed" fixes at the interface of an "adsorbent" solid (Board, 2004). In the last three decades, the drug residue problems have emerged. Some of these molecules have genotoxic or hormono-mimetic properties and can potentially have an environmental impact on aquatic ecosystem (Benchouala, 2016; Emmanuel et al., 2008; Lavilleet al., 2008). Contaminate water is a vector for many diseases, water being one of the most basic constituents of life, cleanliness of water is essential for the sustainable health of the humans, aquatic and wildlife (Bano et al., 2018; Le Pimpec, 2002; Forbes, 1997).

In this work, we used sawdust from carpentry rejects to absorb salicylic acid in its normal state without any modification. We were particularly interested in studying the kinetics of salicylic acid adsorption to predict the best kinetic model of this responded material and to valorize it and benefit from its depolluting properties.

\section{MATERIALS AND METHODS}

\section{Ethical approval}

The experiment was carried out according to the national regulations on animal welfare and institutional animal ethical committee.

\section{Experimental design}

The study was carried out in North-Eastern Algeria through the period from January 2017 to June 2018. The reason we chose to study spruce sawdust, is its availability in private carpentry factories in the Souk Ahras area and the enormous quantities of this wood waste that is thrown into public landfills. The samples were collected randomly from carpenters in the study area by collecting sawdust remains in a plastic sack and then mixed before the experiments. Three solutions with concentrations; 15,10 and $5 \mathrm{mg} / \mathrm{l}$ starting from the solution mother of SS of concentration $20 \mathrm{mg} / \mathrm{were}$ prepared, then we measured absorbance (A) of each solution and we will define here the calibration curve to be a function $f(\mathrm{c})$ the calibration curve $\mathrm{A}=f(\mathrm{c})$.

In a Becher one weighs $\mathrm{m}=50 \mathrm{Mg}$ of the collected sawdust and addition volume of $50 \mathrm{ml}$ of the $\mathrm{SS}$ solution $(\mathrm{C}=20$ $\mathrm{mg} / \mathrm{l}$ ) then we started the stop watch and we took to each five minute, then we filtered and determined the concentration of the filtrate obtained, the operation was stopped when the value of the concentration of balance is constant.

We traced the quantity $(Q)$ retained according to time $(t)$ with the function $f(\mathrm{t}): Q=f(t)$.

One determines the variations of the adsorbed quantity:

$Q=\left(C_{0}-C_{t}\right)$. V/m according to time (Zupanc, 2013).

With $Q$ : the quantity adsorbed, $\mathrm{C}_{0}$ : initial concentration, $\mathrm{C}_{\mathrm{t}}$ : concentration at the moment $\mathrm{t}, \mathrm{V}$ volume of $\mathrm{SS}, \mathrm{m}$ : weight.

\section{Sodium salicylate kinetic models}

In our study we based on two kinetic models, pseudo first order and pseudo-second order, to determinate the best kinetic model for the adsorption of sodium salicylate; These mathematical models were chosen on the one hand for their simplicity and on the other hand for their application in the field of adsorption of organic or inorganic compounds on the various natural and synthetic adsorbents.

\section{Pseudo-first order}

The equation of this model was introduced initially by Lagergren (Simonin, 2016) is form: $\frac{D Q}{D T}=K 1(Q e-Q t)$

With $\mathrm{Q}$ the amount of adsorbed solute, $\mathrm{Q}_{\mathrm{e}}$ its value at equilibrium, $\mathrm{K}_{1}$ the pseudo-first order rate constant and $t$ the time. After the integration and application of the condition limit $(\mathrm{Q}=0$ for $\mathrm{T}=0$ and $\mathrm{Q}=\mathrm{Qe}$ for $\mathrm{t}=\mathrm{t})$ the equation becomes: $\ln (Q-Q e)=\ln (Q e)-K_{l} t$

With Qe: the quantity of the adsorbed residue at equilibrium, $\mathrm{Q}_{\mathrm{t}}$ : quantity adsorbed at the moment $\mathrm{t}, \mathrm{K}_{1}$ : constant the kinetics of the reaction.

\section{Pseudo-second order}

This model is form expressed by the equation (HO and MCKAY, 1999): $\frac{D Q}{D T}=K 2 \times(Q e-Q)$

$\mathrm{Q}_{\mathrm{e}}$ : quantity at equilibrium, Q: quantity adsorbed at the moment $\mathrm{T}, \mathrm{K}_{2}$ (constant): kinetics of the reaction. 
After the integration and application of the same conditions limit preceding, the preceding equation becomes:

$\frac{T}{Q}=\frac{1}{K 2 \times Q e^{2}}+\frac{T}{Q e}$

Q: Amount of adsorbed solute, $\mathrm{Q}_{\mathrm{e}}$ : Value at equilibrium, Q: Quantity adsorbed at the moment $\mathrm{T}, \mathrm{K}_{2}$ (constant) kinetics of the reaction.

\section{Statistical analysis}

The collected data are logged and processed using the program (Microsoft Excel software and Graph Pad Prism) to perform the description and evaluation.

The correlation qualities about adsorption kinetics, the relations for $\mathrm{K}_{1}$ and $\mathrm{K}_{2}$, present as follows:

$\mathrm{Y}=\mathrm{aX}+\mathrm{b}(\mathrm{a}$ and $\mathrm{b}$ are parameters)

\section{RESULTS}

\section{Visible ultraviolet absorption spectrophotometry}

Spectrophotometry is a technique of analysis al-lows, inter alia identifying a chemical substance and of the concentration of an aqueous solution in a solution deter-mines, by the interaction of the electrons of the molecules of the aqueous solution (called chromophoric) with the light (Zupanc, 2013).

The determination of the residual concentration of SS is carried out by proportioning spectrophotometry in the UV screw field, by using the law of Beer-Lambert the wavelength of the maximum absorption of SS is $230 \mathrm{~nm}$ (Figure 1). From the different solutions, we obtained the following calibration curve (Figure 2). Figure 3 shows that the rate of adsorption is higher at the beginning of the processes and then becomes increasingly slow in the course of the time of agitation to reach balance. The time of balance of adsorption of this residue is 44.5 min the quantity selected is 19,91 $\mathrm{mg} / \mathrm{g}$.

The layout of Ln (Qe-Q) according to time for residue SS gives a linear form shown in figure 4. The value of $\mathrm{K}_{1}$ was calculated starting from the slope of this line. $\mathrm{K}_{2}(\mathrm{mg} / \mathrm{g}$. $\mathrm{min})$ is the constant kinetics determined starting from the slope of straight lines $1 / \mathrm{Q}_{\mathrm{t}}$ according to time (Figure 4).

From the set of kinetic parameters provided by these graphs, it is clearly seen that the value of the coefficient of correlation $\mathrm{R}^{2}=0.999$ for the model of pseudo-second order was closer to 1 (Figure 5) and the coefficient of correlation wasR $^{2}=0,997$ for the model of pseudo-first order (Figure 4). Hence the kinetic model pseudo-second order gives a better description of the kinetics the reaction of adsorption SS on the sawdust compared to the pseudo first-order model.

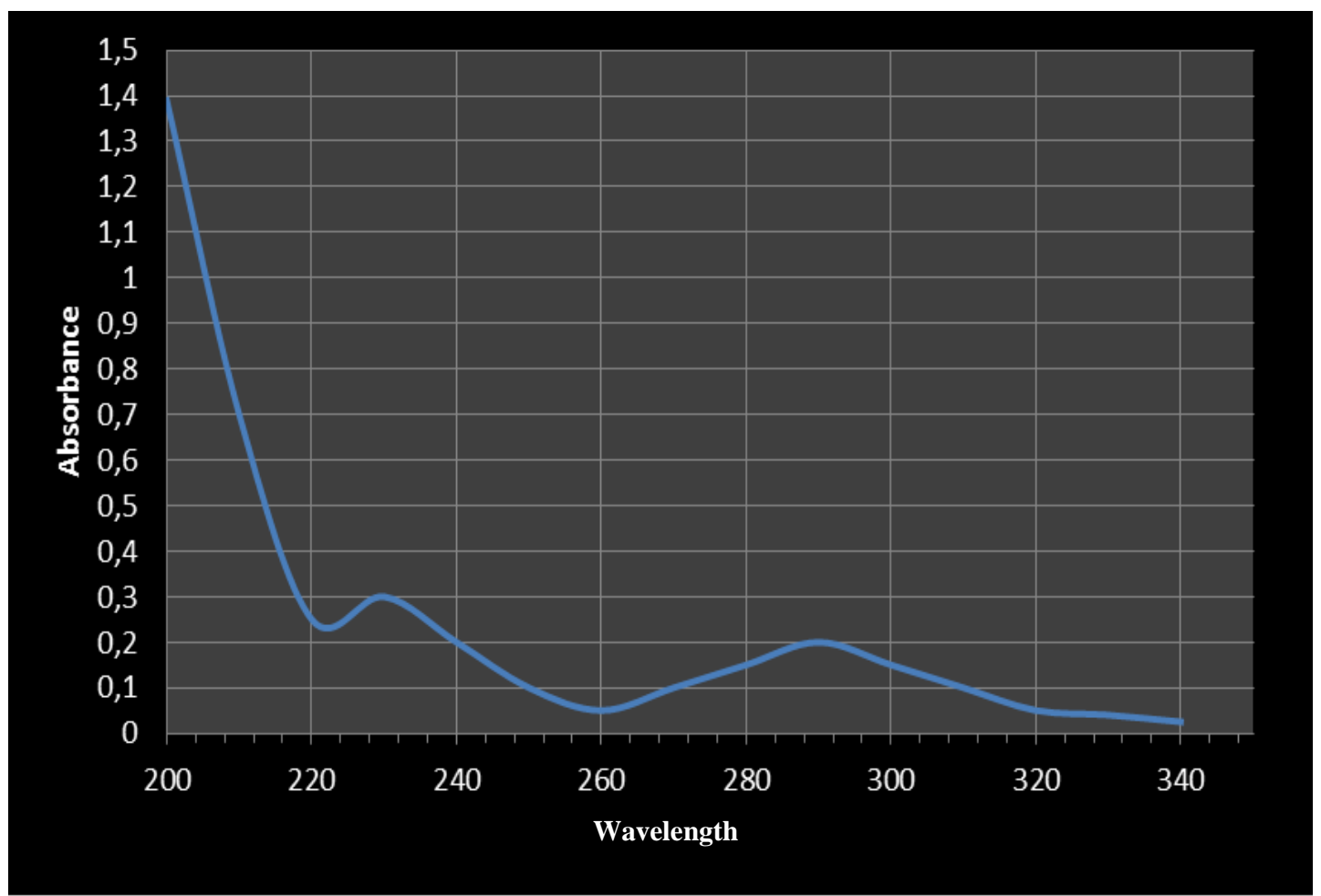

Figure 1. Absorption spectra of sodium salicylate in the ultraviolet field, Eastern Algerian during January 2017 to June 2018 


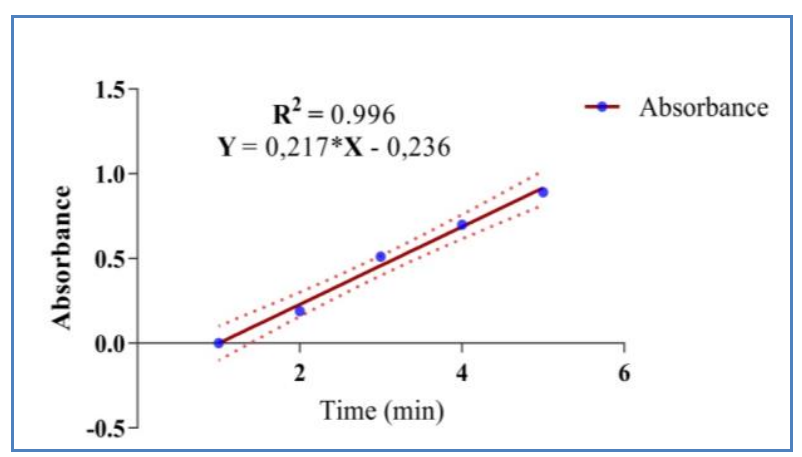

Figure 2. The calibration curve of sodium salicylate, Eastern Algerian during January 2017 to June 2018. R²: the correlation coefficient, Y: Absorbance, X: time.

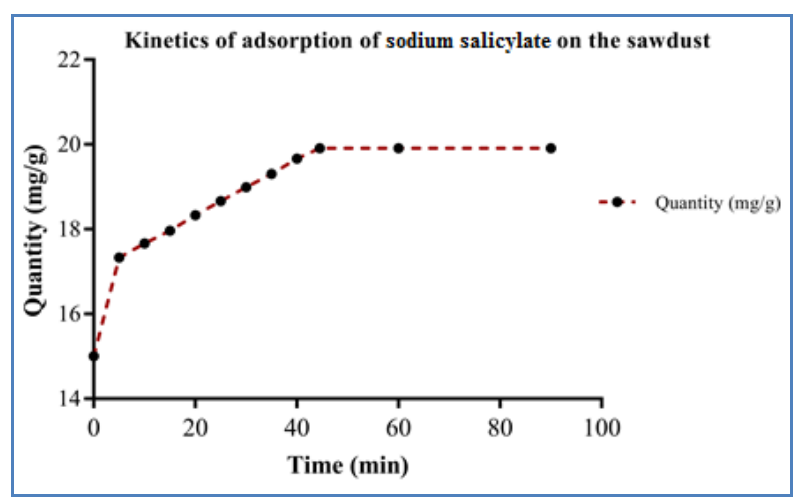

Figure 3. Kinetics of adsorption of sodium salicylate on the used sawdust, Eastern Algerian during January 2017 to June 2018
Linear form of the kinetic model pseudo-first order

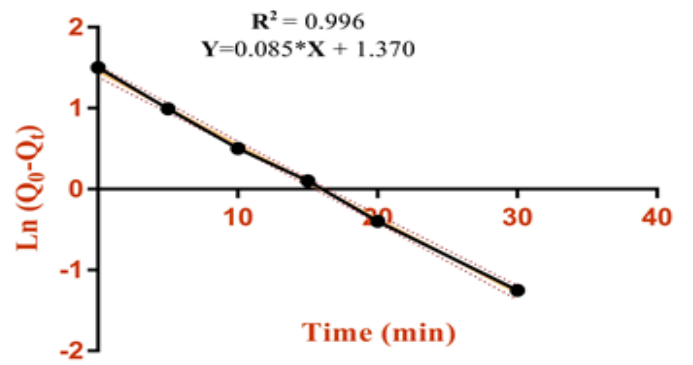

Figure 4. Linear form of the kinetic model pseudo-first order of adsorption of sodium salicylate on the sawdust, Eastern Algerian (January 2017 to June 2018). R ${ }^{2}$ : Correlation coefficient, $\mathrm{Y}$ : $\mathrm{Ln}\left(\mathrm{Q}_{0}-\mathrm{Q}_{\mathrm{t}}\right)$, X: time

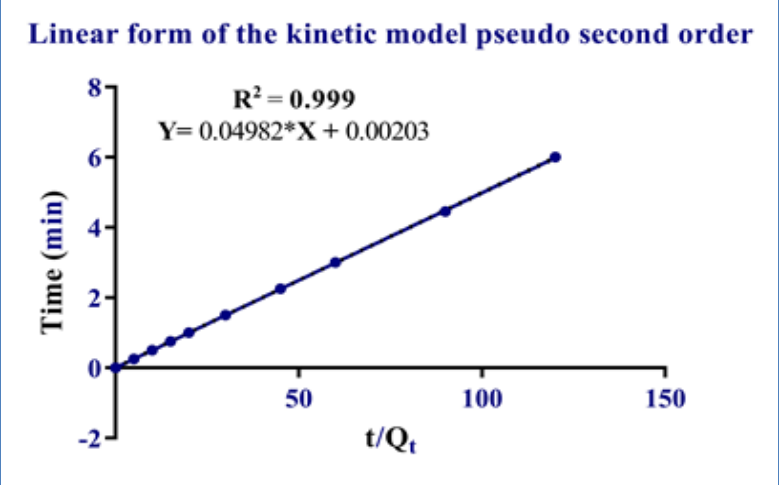

Figure 5. Linear form of the kinetic model pseudo second order of adsorption sodium salicylate (SS) on the sawdust, eastern Algerian (January 2017 to June 2018). $R^{2}$ : Correlation coefficient, $Y$ : time, $X: T / Q_{t}$.

\section{DISCUSSION}

Many studies on the adsorption of dyes, toxic salts and oil from water using sawdust as an adsorbent have been reported, this material has proven that is not only abundant, but it is really an efficient and economic adsorbent (Shukla et al., 2002; Nag, 1995). The components and complexing properties of the sawdust explains the adsorption mechanism, as the cell walls of sawdust which are mainly composed of cellulose, lignin, and many hydroxyl compounds, such as tannins or other phenolic compounds (Suemitsu et al., 1986).

Most of the current literature on liquid/solid adsorption kinetics compares the respective capacities of first-order and second order pseudo-kinetics to describe the data (Simonin, 2016). It is preferable to use the correlation coefficient $\left(R^{2}\right)$ in the comparison of method data to determine the most appropriate models (Lin and Wang, 2009). As a result of the linear models obtained from the kinetic parameters in this study, the value of the correlation coefficient $\left(\mathrm{R}^{2}\right)$ is 0.999 for the pseudo-second order model is closer to 1 and for the pseudo-first order model is 0.997 .

The study of the adsorption kinetics of salicylic acid demonstrated the values and benefits of its depolluting properties but the choice of the most appropriate kinetic model for this material will facilitate the study and give more reliable results (Adib et al., 2018; Giraldo et al., 2018; Mekhalef et al., 2018).

\section{CONCLUSION}

We have introduced a new assay of polluted Kinetic models. Several models are given in the literature to describe the kinetics of adsorption. In our study, we used kinetic laws of the pseudo-first order and of the pseudo-second order establish by Lagergren. Water treatment, as an example we worked on the absorption of SS from sawdust; The comparison of the results obtained by the two models kinetics shows that the pseudo-second order model is the best than kinetic model pseudo-first order for conducting studies of adsorption of SS by sawdust, with a time of contact solid/liquid optimal of 44,5 minutes. 


\section{DECLARATIONS}

\section{Competing interests}

The authors have no competing interests to declare.

\section{Consent to publish}

All authors gave their informed consent prior to their inclusion in the study.

\section{Acknowledgements}

The authors are thankful to the University of Mohamed Cherrif Mesaadia, Souk Ahras for the support and allowing this research work to be performed. We also would like to appreciate all participants who contributed during the performance of the research, especially Pr. Bennoune Omar, Also, all the gratitude for Pr. Melizi Mohamed, who had his particular and unforgettable way of helping the involved ones in the team. To all our students of the agro-veterinary institute Taoura.

\section{Author`s contributions}

Berghiche created the idea of the study, Berghiche and Boulebda participated in the design of study, Berghiche collected samples. Slimi and Boudis performed the experiments and collected Data, Berghiche, Khenenou and Labiad were involved in the collection of data, statistical analysis and drafting of the manuscript. Khenenou, Boulebda critically revised the manuscript, Khenenou, Boulebda and Berghiche read and approved the final manuscript.

\section{REFERENCES}

Adib M, El Kouali M, and Talbi M (2018). Experimental Study of The Elimination of a Textile Dye by the Adsorption Phenomenon on Beech Wood Sawdust. International Journal of Chemical Sciences, 16(1): 239.

Aloulou F, Boufi S, Belgacem N and Gandini A (2004). Adsorption of cationic surfactants and subsequent adsolubilization of organic compounds onto cellulose fibers. Colloid and Polymer Science, 283(3): 344-350. Doi: http://dx.doi.org/10.1007/s00396- 004$1143-\mathrm{y}$

Arami M, Limaee NY, Mahmoodi NM and Tabrizi NS (2005). Removal of dyes from colored textile wastewater by orange peel adsorbent: equilibrium and kinetic studies. Journal of Colloid and interface Science, 288(2): 371-376. Doi:https://doi.org/10.1016/j.jcis.2005.03.020

Benchouala A (2016). Écotoxicité, cytotoxicité et potentielandrogène des résiduspharmaceutiquessur les deuxmodèles biologiques: Hydra attenuata et les cellules MDA-Kb2 (Doctoral dissertation, Université de Lorraine) pp.33-37.

Board NIIR (2004). Hand Book on herbs cultivation \& processing (pp. 50-54). Asia Pacific Business Press.

Bano I and Arshad M (2018). Climatic Changes Impact on Water Availability. In Perspectives on Water Usage for Biofuels Production Springer, Cham, pp. 39-54. Doi:https://doi.org/10.1007/978-3-319-66408-8_2

Charuaud L, Jardé E, Jaffrézic A, Thomas MF and Le Bot B (2018). Veterinary pharmaceutical residues from natural water to tap water: Sales, occurrence and fate. Journal of hazardous materials, 361(1): 169-186. Doi:https://doi.org/10.1016/j.jhazmat.2018.08.075.

Derelanko MJ (2017). The toxicologist's pocket handbook. CRC Press Taylor \& Francis Group, third edition, 81p.

Emmanuel E, Theleys K, Lacour J, Plancher MJ, Marseille JA, Balthazard-Accou K and Joseph O (2008). Pollution et altération des eaux terrestres et maritimes en Haïti. Gestion des ressources en eau et développement local durable: Caraïbe, Amérique latine, Océanindien, 5, 165.

Figuière C, Boidin B and Diemer A (2018). Political economy of sustainable development. De Boeck Superieur, 2nd Edition, 278p. (French version).

Forbes VE and Forbes TL (1997). Ecotoxicologie: théorie et applications. Editions Quae, first edition, pp 50-55.

Forgacs E, Cserhati T and Oros G (2004). Removal of synthetic dyes from wastewaters: a review. Environment international, 30(7): 953-971.

Giraldo L, Moreno-Piraján JC, Fonseca RA, Húmpola P and Odetti HS (2018). Water Depollution Using Activated Carbons from Aerogels and Bones. In Green Adsorbents for Pollutant Removal (pp. 183-226). Springer, Cham. Doi:https://doi.org/10.1007/978-3-319-92162-4_6

Gupta VK, Carrott PJM, RibeiroCarrott MML and Suhas (2009). Low-cost adsorbents: growing approach to wastewater treatmentreview. Critical Reviews in Environmental Science and Technology, 39(10): 783-842 https://doi.org/10.1080/10643380801977610

Harris DC (2010). Quantitative chemical analysis. Macmillan, 3rd edition, W.H. Freeman: New York, pp 279-299.

Hazourli S, Ziati M, Hazourli A and Cherifi M (2007). Valuation of a natural ligno-cellulosic residue into activated charcoal - e. g. date nuclei. Revue des Energies Renouvelables, ICRESD, 7: 187-192. (french version). 
Ho YS (2006). Review of second-order models for adsorption systems. Journal of hazardous materials, 136(3): 681-689. Doi:https://doi.org/10.1016/j.jhazmat.2005.12.043

Ho YS and McKay G (1999). Pseudo-second order model for sorption processes. Process biochemistry, 34(5): 451-465. Doi:https://doi.org/10.1016/S0032-9592(98)00112-5

Ho YS and McKay G (1998). A comparison of chemisorption kinetic models applied to pollutant removal on various sorbents. Process safety and environmental protection, 76(4): 332-340. Doi: https://doi.org/10.1205/095758298529696

Ho YS, Chiu WT and Wang CC (2005). Regression analysis for the sorption isotherms of basic dyes on sugarcane dust. Bioresource technology, 96(11): 1285-1291. Doi:https://doi.org/10.1016/j.biortech.2004.10.021

Jones OAH, Voulvoulis N and Lester JN (2004).Potential ecological and human health risks associated with the presence of pharmaceutically active compounds in the aquatic environment. Critical reviews in toxicology, 34(4): 335-350. Doi:https://doi.org/10.1080/10408440490464697

Juan G, Barataud F, Benoit P, Bouchet L, Carpentier A, Gouy V and Voltz M (2018). Reference manual on research tools to reduce water pollution by pesticides. Final report, Institut National de la Recherche Agronomique et Agence Française pour la Biodiversité convention, 180 p. (french version).

Kyzas G Z, Fu J and Matis KA (2013).The Change from Past to Future for Adsorbent Materials in Treatment of Dyeing Waste Waters. Materials, 6(11): 5131-5158. Doi:https://doi.org/10.3390/ma6115131

Laville N, Aït-Aïssa S, Casellas C and Porcher JM (2006). Application of in vitro models to study drug effects in fish. Environment, Risks and Health, 5(4): 284-289. (french version).

Le Pimpec P (2002). Practical guide for the sampling agent in charge of policing aquatic environments. Editions Cemagref, first edition, pp. 129-133. (french version).

Limbu SM, Zhou L, Sun SX, Zhang ML and Du ZY (2018). Chronic exposure to low environmental concentrations and legal aquaculture doses of antibiotics cause systemic adverse effects in Nile tilapia and provoke differential human health risk. Environment international, 115: 205-219. Doi:https://doi.org/10.1016/j.envint.2018.03.034

Lin J and Wang L (2009). Comparison between linear and non-linear forms of pseudo-first-order and pseudo-second-order adsorption kinetic models for the removal of methylene blue by activated carbon. Frontiers of Environmental Science and Engineering in China, 3(3): 320-324. Doi:https://doi.org/10.1007/s11783-009-0030-7

Meadows D and Randers J (2012). The limits to growth: the 30-year update. Routledge, London, , first edition, p. 362. Doi:https://doi.org/10.4324/9781849775861

Mekhalef Benhafsa F, Kacha S, Leboukh A and Belaid K (2018). Étude comparative de l'adsorption du colorant Victoria Bleu Basique à partir de solutions aqueuses sur du carton usagé et de la sciure de bois. Journal of Water Science, 31(2): 109-126. Doi:https://doi.org/10.7202/1051695ar.

Nag A (1995). Utilization of charred sawdust as an adsorbent of dyes, toxic salts and oil from water. Process safety and environmental protection, 73(4): 299-306.

Ofomaja A E and Ho YS (2007). Equilibrium sorption of anionic dye from aqueous solution by palm kernel fibre as sorbent. Dyes and Pigments, 74(1): 60-66. Doi:https://doi.org/10.1016/j.dyepig.2006.01.014

Pekkuz H Uzun I and Güzel F (2008). Kinetics and thermodynamics of the adsorption of some dyestuffs from aqueous solution by poplar sawdust. Bioresource Technology, 99(6): 2009-2017. Doi: https://doi.org/10.1016/j.biortech.2007.03.014

Shukla A, ZhangYH, Dubey P, Margrave JL and Shukla SS (2002). The role of sawdust in the removal of unwanted materials from water. Journal of Hazardous Materials, 95 (1-2): 137-152. Doi:https://doi.org/10.1016/S0304-3894(02)00089-4

Simonin JP (2016). On the comparison of pseudo-first order and pseudo-second order rate laws in the modeling of adsorption kinetics. Chemical Engineering Journal, 300: 254-263. Doi:https://doi.org/10.1016/j.cej.2016.04.079

Suemitsu R, Osako M and Tagiri N (1986).Use of dye-treated sawdust for removal of heavy metals from wastewater. Science Energie Revue, 27: 41-48.

Toillier A (2018). Assess and strengthen the adaptive capacities of family farmers: Estmalgache's forest populations in the face of conservation measures. Editions Quae, NSS-dialogues, France, 127 p. (french version).

Zhang YHP, Cui J, Lynd LR and Kuang LR (2006).A transition from cellulose swelling to cellulose dissolution by o-phosphoric acid: evidence from enzymatic hydrolysis and supramolecular structure. Biomacromolecules, 7(2): 644-648. Doi:10.1021/bm050799c

Zupanc M, Kosjek T, Petkovšek M, Dular M, Kompare B, Širok B and Heath E (2013). Removal of pharmaceuticals from wastewater by biological processes, hydrodynamic cavitation and UV treatment. Ultra Sonicssonochemistry, 20(4): 1104-1112. Doi:https://doi.org/10.1016/j.ultsonch.2012.12.003 